\title{
SELEBTWITS: MICRO-CELEBRITY PRACTITIONERS IN INDONESIAN TWITTERSPHERE
}

\author{
Detta Rahmawan \\ Newcastle University, UK
}

\begin{abstract}
Drawn from the notion that Twitter is a suitable context for micro-celebrity practices (Marwick, 2010) this research examines interactions between Indonesian Twitter-celebrities called selebtwits and their followers. The results suggest that several strategies include: stimulated conversation, audience recognition, and various level of self-disclosure that have been conducted by the selebtwits to maintain the relationship with their followers. This research also found that from the follower viewpoint, interaction with selebtwits is often perceived as an "endorsement" and "achievement". However, there are others who are not particularly fond of the idea of the selebtwits-follower's engagement. Some selebtwits-followers' interactions lead to "digital intimacy", while others resemble parasocial interaction and one-way communication. Furthermore, this study suggests that in the broader context, selebtwits are perceived in both positive and negative ways.
\end{abstract}

Keywords: Twitter, social media, micro-celebrity, selebtwits

\section{SELEBTWIT: MICRO-CELEBRITY DALAM RUANG TWITTER DI INDONESIA}

\begin{abstract}
ABSTRAK
Twitter adalah salah satu media sosial di mana wacana mengenai micro-celebrity berkembang (Marwick, 2010). Berangkat dari hal tersebut, penelitian ini bertujuan untuk melihat wacana micro-celebrity di Indonesia dengan menganalisis interaksi yang terjadi diantara selebritis Twitter Indonesia yang disebut selebtwit dengan para followers (pengikut) nya. Penelitian ini menemukan bahwa terdapat beberapa strategi komunikasi yang dilakukan oleh para selebtwit untuk menjaga hubungan dengan para followers-nya, antara lain: percakapan yang terstimulasi, pengakuan terhadap followers sebagai khalayak, dan berbagai strategi pengungkapan diri. Hasil lain menunjukkan bahwa dari sudut pandang para followers, interaksi mereka dengan para selebtwit sering dipandang sebagai sarana untuk promosi diri. Beberapa diantara mereka juga melihat interaksi ini sebagai sebuah prestasi. Namun di sisi lain, terdapat pula sebagian followers yang tidak begitu tertarik untuk melakukan interaksi secara lebih personal kepada para selebtwit. Beberapa bentuk interaksi yang telah dianalisis dalam penelitian ini memperlihatkan konsep "keintiman digital". Tetapi di pihak lain terjadi pula interaksi yang bersifat "parasosial" dan satu arah. Lebih jauh, studi ini memperlihatkan bahwa dalam konteks yang lebih besar, selebtwit sebagai manifestasi dari wacana micro-celebrity dapat dimaknai secara positif maupun negatif.
\end{abstract}

Kata-kata kunci: Twitter, media sosial, micro-celebrity, selebtwit

Korespondensi: Detta Rahmawan, S.I.Kom., MA. Newcastle University, NE1 7RU, United Kingdom. Email:dta.r44@gmail.com 


\section{INTRODUCTION}

Vanessa Grigoriadis, a contributing editor at Vanity Fair wrote an article entitled "American Tweethearts" which tells the story of a group of wealthy, attractive young women who live in places like New York and California, and become famous on Twitter - a micro-blogging service with social networking features - called the "Twilebrity" (2010). These women are not conventionally famous in the same way as Angelina Jolie or Madonna; rather, they are just common people and non-public figures. The "Twilebrity" phenomenon illustrates the emergence of Internet-celebrity created by the propagation of Twitter.

The trend of people who become famous online has been studied by Theresa Senft, who coined the term "micro-celebrity" to refer to women called "Camgirls"; such women broadcast their lives and construct their identities over the Internet via webcams and LiveJournal ${ }^{1}$ (2008). Micro-celebrity can be understood as set of practices or "techniques" on social media in which people construct a self-presentation with various tactics and strategies drawn from advertising and marketing discourses (Marwick, 2010). As a result, some people often deploy and maintain their online identities "as if it were a branded good" (Senft, 2012, p. 1). The notion of identities as "brand" within online environments is particularly apparent in one of today's most popular social media, Twitter.

Micro-celebrity practitioners often see their followers as a fan base, and that they often construct their online personas for the consumption of others (Marwick, 2010; Marwick \& boyd, 2010). Within academic discourses, research on micro-celebrity practices is mainly focused in the US or European contexts, while similar phenomena in other places have yet to be examined. This research selected Indonesia for several reasons: social media users in Indonesia have grown at tremendous speed (Lim, 2012) and Indonesia's capital city Jakarta is considered the most active "Twitter City" in the world. It has been suggested that Indonesians "generated more Tweets than anywhere else on earth" (Semiocast, 2012; Saleh, 2013). Some Twitter us-

1 LiveJournal is a social network sites where users can write a blog, diary, or journal: http://www.livejournal.com/ ers in Indonesia has become widely famous and considered as Twitter-celebrities or selebtwits (Maulia, 2013; Jakarta Globe, 2013) which resemble the notion of micro-celebrity practices on Twitter (Marwick, 2010; Marwick \& boyd, 2010). Hence, to extend the line of study about micro-celebrity practices, this research examines interactions which occur between selebtwits and their followers, and discuss the broader issues related to this phenomenon.

\section{METHODOLOGY: ETHNOGRAPHY}

This research seeks to analyze interactions between selebtwits and their followers in Indonesian Twittersphere ${ }^{2}$. For this purpose, ethnography as a methodology has been used for collecting data: including brief interviews, observations and discourse analysis to examine the broader issues surrounding the selebtwits phenomenon. Ethnography is an approach which requires "participating, overtly or covertly, in people's daily lives for an extended period of time, watching what happens, listening to what is said, asking questions - in fact, collecting whatever data are available to throw light on the issues that are the focus of the research" (Hammersley, 1995, p. 1). The following research is divided into two phases: the first phase identifies the selebtwits, and collects data from relevant sources on the Internet which related to this phenomenon, and the second observes in detail the interactions between selebtwits and their followers,

The first phase of this research identifies selebtwits and finds examples of them. To do so, I posted questions to my own followers and sent@ @reply questions or direct messages to follow up on their answers. While all the Twitter accounts I reference are public, I have anonymized all of my respondents. My questions included: "Do you know about "selebtwits"?", "In your opinion, who are selebtwits?", "Why are these selebtwits famous?", and so on. These questions were not fixed and some of them were slightly modified according to the respondents' answers. I used informal Bahasa Indonesia (In-

2 Twittersphere refers to "the community of people who use the microblogging service Twitter, and all the messages that they put on the Internet" (http://www.macmillandictionary. com/dictionary/british/twittersphere) 
donesian Language) to make the process feel informal and more like a daily conversation. To ensure that the selebtwits who were identified by the respondents were not fictional, a background check was completed of these individuals' Linkedin ${ }^{3}$ profiles, in addition to reading their blogs or personal webs, etc. Data were also collected from some of Indonesian online news, Twitter search features, and other relevant materials from the Internet to reveal additional facts about what a selebtwit is and how Indonesian perceived this phenomenon.

In Interactions between Selebtwits and their Followers, I asked further questions to the respondents such as: "Do you 'follow' these selebtwits?", "Why do you follow (or not follow) them?", "What kinds of interactions usually occur between you and the selebtwits?" etc., to know what kind of interactions occurred between the respondents and the selebtwits. To discover the way the selebtwits presented themselves and interacted with their followers to maintain their popularity, I read two months' of these individuals' tweets, check their mention tabs and observed their content type. Analysis was also performed to find out how their followers connect and interact with them. For analytical purposes, some examples were selected to illustrate the results. The data obtained are not quantified; rather, "thematic" categories and descriptions (Ryan \& Bernard, 2003) has been used as the analytic tool. Ethnographic study on social media emphasizes how people in a particular place understand their own social media use (Marwick, 2010). Since this study employ qualitative method and only uses a very small set of data, the results cannot be generalized for all of the micro-celebrity practitioners in Indonesia. Future empirical works might strengthen this topic with a broader set of participants and data.

\section{RESULTS \& ANALYSIS}

From the 65 Twitter users who responded to my questions, nearly all were well-informed about the selebtwits phenomenon, although they conceptualized it in various ways. The majority of respondents identified them as "or-

3 Linkedin is a social network sites which mostly used for professional networking (http:// en.wikipedia.org/wiki/LinkedIn) dinary people", famous on Twitter, and having large numbers of followers. Although all of the respondents emphasized the importance of follower count (see figure 1), what they meant by "large numbers of followers" varied. Some respondents said 5,000 followers was enough while others thought the minimum amount was more than 10,000. Selebtwits' popularity can also considered from the way people reacted to their tweets. With a large number of followers, almost all of their activity on Twitter obtained constant feedback from their followers in the form of retweets or replies.

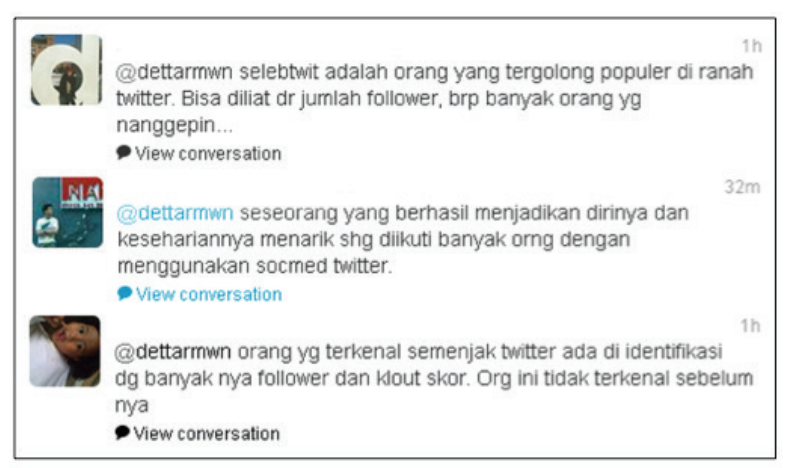

Figure 1. 1 Example of responses

Female user(1): @dettarmwn ${ }^{4}$ Selebtwits are someone who can be categorized as well-known people in the Twittersphere. It can be seen from (their) follower count, (and) how many people reacted (to their tweets).

Male user (2): @dettarmwn (Selebtwits are) someone who successfully made themselves and their daily activities interesting via social media (Twitter) thus many people are following them.

Female user (2): @dettarmwn (Selebtwits are) someone who become famous in Twitter (which can be) identified by follower count and klout score ${ }^{5}$. These

$4 @$ @ettarmwn is my username on Twitter

$5 \quad$ Klout is one of the most popular analytic tools within internet marketing, which ranks people according to their "online social influence" (http://en.wikipedia.org/wiki/Klout). 
people are not famous beforehand.

Some respondents noted that selebtwits are avid users who tweet more frequently than average users. Their tweets also have original characteristics or particular "themes" which made them unique. Examples of these characteristics are being "funny", "witty", "insightful", "romantic", "informative" or "nyinyir"6 (see figure 2).

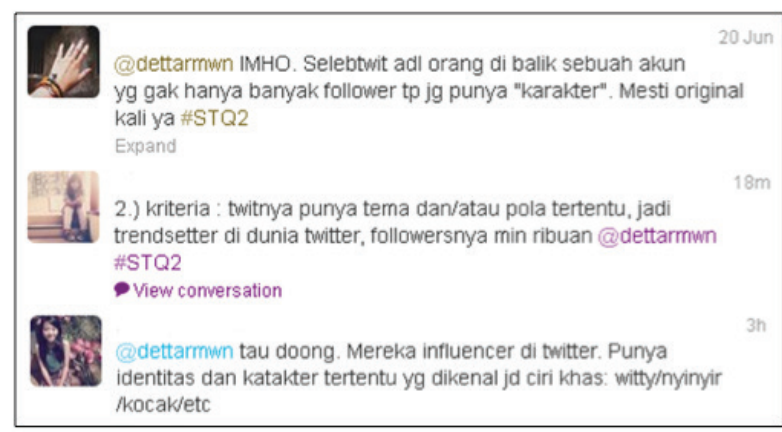

Figure 1. 2 Example of responses

Female user (1): @dettarmwn IMHO (In my honest opinion) a selebtwit is someone behind a (twitter) account who not only has a large number of followers but (they) also have a (certain) "character". (And) they must be original.

Female user (2): Criteria: their tweets have certain themes/patterns, (they) become (a) trendsetter in the world of Twitter, (and) they at least have thousands of followers@dettarmwn \#STQ2 ${ }^{7}$

Female user (3): @dettarmwn Of course I know, they are "the influencer" on Twitter. (They) have a particular identity and character which made them wellknown: witty/nyinyir/funny/ etc.

6 "Nyinyir" is an idiom in the Indonesian language which can be interpreted as the act of commenting on people in sarcastic and/or negative tone.

$7 \quad$ \#STQ is a hashtag that I used to keep track of the questions
Examples of users who were identified by the respondents as selebtwits were the following: @newsplatter@ndorokakung,@rahneputri,@ amrazing,@miund,@zarryhendrik,@hotradero, etc. Their Linkedin profiles, which held their professional backgrounds, and their personal webs, blogs and other online materials which contained information about them were obtained from Google search. All of these people were professionals working in Jakarta, the capital city of Indonesia. They had been tweeting for more than two years (checked by free twitter analytics twitaholic.com and twittercounter.com) and all of them had more than 50.000 followers. Analysis about the selebtwits in the broader context also has been done to obtain further information which related to this phenomenon. The results suggest that selebtwits are perceived in both positive and negative ways.

The Selebtwits are "ordinary people" who become micro-celebrity practitioners, and in doing so resemble the concept of the "demotic turn" (Turner, 2010) on social media. As Twitter-related celebrities, apparently their popularity is not limited only on the Twittersphere. Some of these individuals utilize their online visibility and influence for various purposes; such as for marketing, political campaign, and so on. Micro-celebrity practitioners might not be that different from "real" celebrity ${ }^{8}$. It has been said that celebrities can utilize their fame for social or economic gain. Akin to real life celebrities who often produce their own products, such as clothing lines (Hewett, 2013), some selebtwits also produce their own goods, particularly books (Tribun News, 2013; Satvika, 2012a). User such as@rahneputri (70,657 followers) and@amrazing (393,393 followers) is the example of selebtwits who have successfully published their own books (see figure 3). Furthermore, in the discourse of marketing, selebtwits' influence is useful for advertising purposes or product endorsement: creating "buzz" within digital marketing campaigns in Indonesia (Daily Social, 2013; Paramaditha, 2013).

8 By "real celebrity" I refer to celebrity practitioners who is widely famous such as Brad Pitt, Angelina Jolie, etc

9 The term "buzz" refers to "marketing buzz" as an advertising technique in Web 2.0 (http://en.wikipedia.org/wiki/Marketing_buzz). 


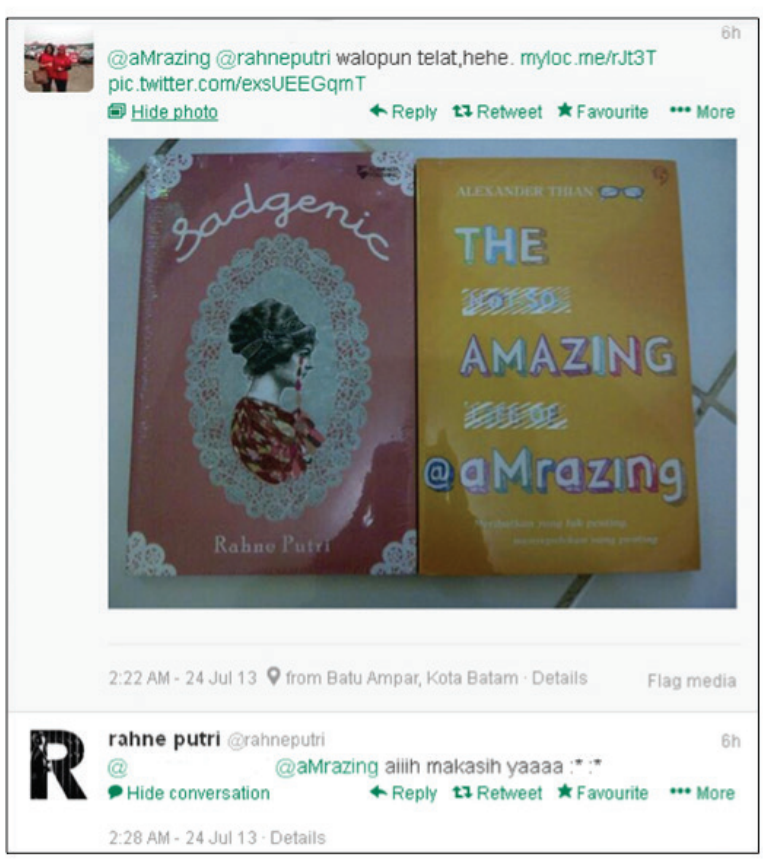

Figure 1. 3 Example of selebtwits' books.

One user mentioned@rahneputri and@ amrazing and told them that she bought their books.@rahneputri then retweeted her tweet and replied to her.

Female user:@amrazing @rahneputri I know it is late, but (she implied that she has just recently bought their books) hehe

@rahneputri:@(users)@amrazing aiiih thank you :* :*

Politics and public affairs also play an important role on Indonesian Twittersphere. It has been suggested that in Indonesia, social media has now become "a potential new battleground" for politicians and also for generating public movements and other activism (Lim, 2012; Jakarta Post, 2013). Study found that there are political influencers such as these selebtwits who come from a range of different backgrounds (Burson-Marsteller, 2012). While it still remains to be seen whether or not these selebtwits will continue to have important roles on the emergence of digital campaign in Indonesia, their existences as "the Twitter influencers" are perceived positively.

The opportunity to monetize influence can be seen as one of the most important factors of why people want to build their online reputation. However, in the broader context, there are interesting issues in that Selebtwits are perceived negatively. For example, the screenshot below shows some of the users who suggests that selebtwits can be a writer only because of their fame and not because of their writing ability (see figure 4).

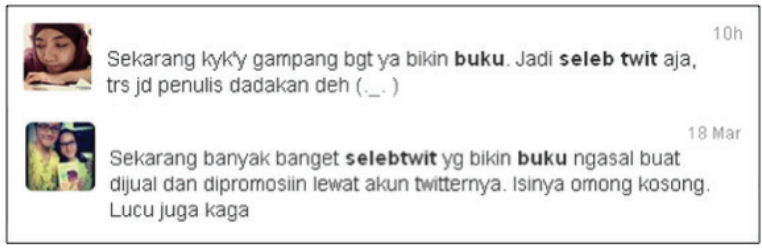

Figure 1. 4 Negative perceptions of selebtwits

Female user (1): Nowadays it seems very easy to publish a book. (You) Should become seleb twit, hence (you) can (immediately) become a writer.

Female user (2): Nowadays, there are so many selebtwits who write and sell random books, and promote them from their Twitter accounts. (Their) Books are nonsense and they are not even funny.

The term "celebrity", commonly understood as "a famous person", sometimes creates a schism: either you are celebrity or you are not (Marwick \& boyd, 2011). The label selebtwits or "Twitter-celebrities" at some extent creates a distinction between Twitter-celebrities and "ordinary" users. Rahne Putri, using username @ rahneputri on Twitter in an interview admitted that the way people talk about selebtwits are somewhat exaggerated and made her uncomfortable (Tribun News, 2013). User such as @ zarryhendrik (125,000 followers) complains about the emergence of "selebtwits-haters", and @ Pitra (11,000 follwers) bluntly said that he does not like that label (see figure 5).

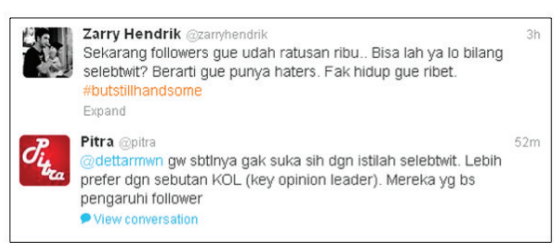

Figure 1. 5 Users who uncomfortable with the label selebtwits 
@,Zarryhendrik: Now I have a hundred thousand followers... so you can call me aselebtwit right? It means I have haters. Fak My life is complicated \#butstillhandsome.

@Pitra: @dettarmwn Actually, I do not really like the term selebtwit. I prefer $K O L$ (Key Opinion Leader) as people who can affect followers.

It has been said that some people adore celebrities, and others dislike them. The analysis suggests that selebtwits as ordinary people who have gained popularity and are seen as Twitter celebrities also create both positive and negative perceptions. Yet, up to this moment, selebtwits' discourse still persists as a frequently discussed topic on Indonesian Twittersphere.

In Indonesian's selebtwits interactions, as micro-celebrity practitioners, selebtwits attract a great deal of attention and responses from other Twitter users. Selebtwits use Twitter for various purposes. They use it to tell others about their daily lives, articulate their opinions, and chat with their followers. The next part of the analysis will discuss several examples which have been chosen to illustrate selebtwits-followers' interactions.

The first example comes from user “@ newsplatter", who had around 65,700 followers. @newsplatter's real name is Henry Manampiring, a professional who works in Leo-Burnett advertising agency in Jakarta, Indonesia (Campaign Brief Asia, 2013) He is an active blogger in http://manampiring17.wordpress.com/and he also wrote his own book which was published by Gramedia, one of the biggest book publishers in Indonesia (Gramedia, 2012). On Twitter, Henry is widely recognized because of his witty, humorous, and sometimes "nerdy" tweets, which cover various themes ranging from his daily life and commentary on Indonesian news headlines, to random jokes, inspirational quotations, books, movies, and gadget reviews.

With 65,700 followers, his tweets frequently receive immediate feedback from his followers. From the observations, the majority of his tweets are light, and funny. He rarely tweets on serious issues such as politics or religion, but when he does, he usually wrapped it with jokes to make them lighter; hence, his followers also interact with him in similar light-humorous tones. He often refers to his audience by collective nouns such as "tweeps", "tuips", "guys" which resembles one-to-many communication. $\mathrm{He}$ also often "stimulates" conversation and asked his followers to participate in particular activities, such as surveys with a witty or unusual theme. His last "project" was what he called a "national survey of ex-girlfriends/boyfriends" (survey mantan nasional). The results of the survey are then published and discussed either on his blog ${ }^{10}$ or on his timeline, often by using particular hashtags such as "\#surveymantan" (see figure 6).

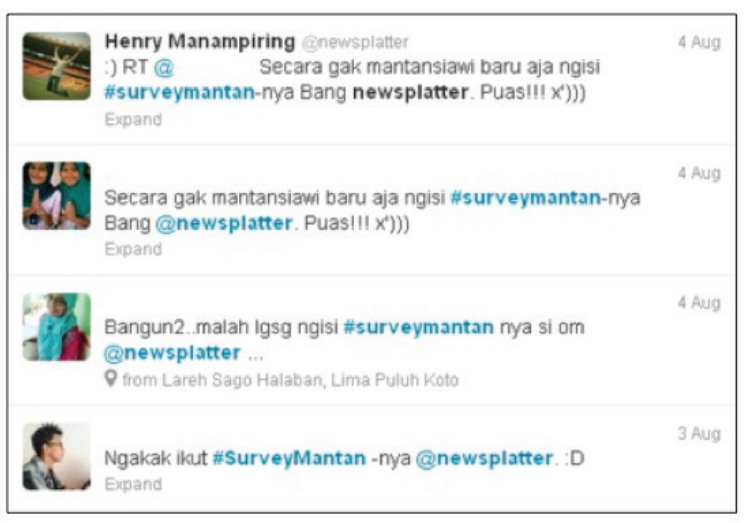

Figure 1.6 Reaction of @newsplatter's \#surveymantan.

@newsplatter: :) RT Female users (1) (I have) just filled @newsplatter's \#surveymantan. I (am) satisfied $\left.\left.x^{\prime}\right)\right)$ ).

Female user (1): (I have) just filled @ newsplatter's \#surveymantan. I (am) satisfied $\left.x^{\prime}\right)$ )).

Female user (3): Just woke up... and directly filled@newsplatter's \#surveymantan....

Male users (4): laughing hard (while) filling @newsplatter's \#surveymantan.

While@newsplatter's ways of communicating with followers are not always in the form of two-way conversations, and some of the conversations were stimulated, he always tried to recognize the existence of his followers by responding and retweeting some of the

10 See: http://manampiring17.wordpress. com/2013/08/06/laporan-survey-mantan-nasional-2013/ 
interesting replies that he received. Generally, @ newsplatter's interactions with his followers are consistent with the way he presents himself as someone who is fun, witty and humorous, which strengthened the argument about the importance of "uniqueness" for the selebtwits.

Communicating via Twitter has become a daily routine for selebtwits as micro-celebrity practitioners. To maintain a connection with their followers, they often give snippets of their daily activities, inviting their followers to see parts of their private life. These self-disclosure strategies produce a sense of intimacy, which in turn may sustain and further cultivate social ties between them and their followers. To illustrate this, the following is an example from Alexander Thian, a 31-year-old businessman, script editor, blogger at http://amrazing.com/ and book writer in Jakarta, Indonesia, who is widely recognized as@amrazing in Twitter.With 393,393 Twitter followers, he is considered one of the most well-known selebtwits in Indonesian Twittersphere.

(a)amrazing's tweets contain various types of topics ranging from jokes, discussion about Hollywood movies and pop culture to viral events on the Internet, but mostly he often tells random stories about his work, friends and daily life. The way he opened himself up with a stream of everything that is going on with his life invites his followers to feel "connected" with him. Trivial, mundane tweets about the movie that he watched, his lunch, conversations with his boss, etc. were often seen on his timeline. He also frequently tells his followers about his cats, posts their pictures, and tells his followers about the name of each cat, and so on (see figure 7).

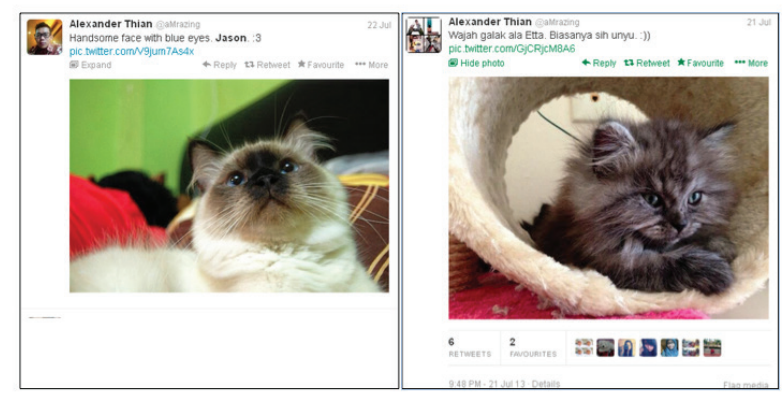

Figure 1.7 Examples of @amrazing's tweets about cats. @amrazing (1): Handsome face with blue eyes, Jason :3

@amrazing (2): Etta's scary face. She usually cute though.. :)).

Almost all of the conversations between @ amrazing and his followers use informal language and often use emoticons as emotional expressions. When one of @amrazing's cats was sick, he talked about it on Twitter, and immediately his followers replied with comforting messages to tell him that they hoped his cat recovered quickly (see figure 8). His self-disclosure and the way the followers interact with him resemble "digital intimacy" (Thompson, 2008), which illustrates the notion that following a person's tweets over a period of time may "create an equally valid feeling of 'knowing' them" (Marwick \& boyd, 2011, p. 148).

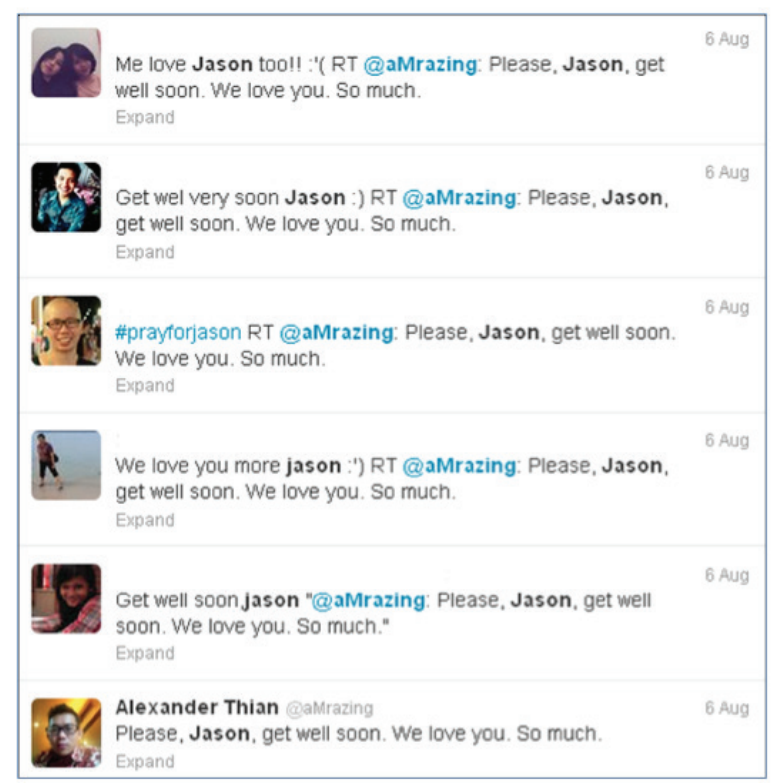

Figure 1. 8: Examples of intimate messages from @ amrazing's followers.

Many users seem eager to get attention from the selebtwits, and these people frequently engage with selebtwits as if they were their friends. Drawn on the example of @amrazing's sick cats (figure 8), his followers send intimate messages and talk as if they know each other. They still continue to mention and reply to him even if they know that he may not reply back. While this may seem meaningless, there are users who enjoy being replied to by these selebtwits and perceive this interaction as some 
kind of "achievement". The screenshot below (see figure 9) shows one female user who was being mentioned by the selebtwits@zarryhendrik, and then she talked about it by posting a screen capture of her public timeline. After that, some of her friend replied her, and they engage in a conversation which suggests that being replied to by selebtwits is some kind of achievement.

Female user (1): Hahaha, since (my) bb (blackberry) does not have screen capture, so here it is, being mentioned by \#zarryhendrik :*.

Female user (2): Eciye ciyee $^{11}$, , (you're) being mentioned by@zarryhendrik.

Female user (3): Ihiwww you should retweet his reply \#zarryhendrik.

Female user (1): (replied to female user $1 \& 2$ ) I have already "favorited ${ }^{12}$ " it.

11 Both "eciye ciyee" and "ihiwww" is a similar expression with "wow" or "whoa" in English

12 "Favorite" is one feature on Twitter which used for saving someone's tweets. By favorited the tweet where she was being mentioned by@zarryhendrik, she she save it as a "commemorative tweet".

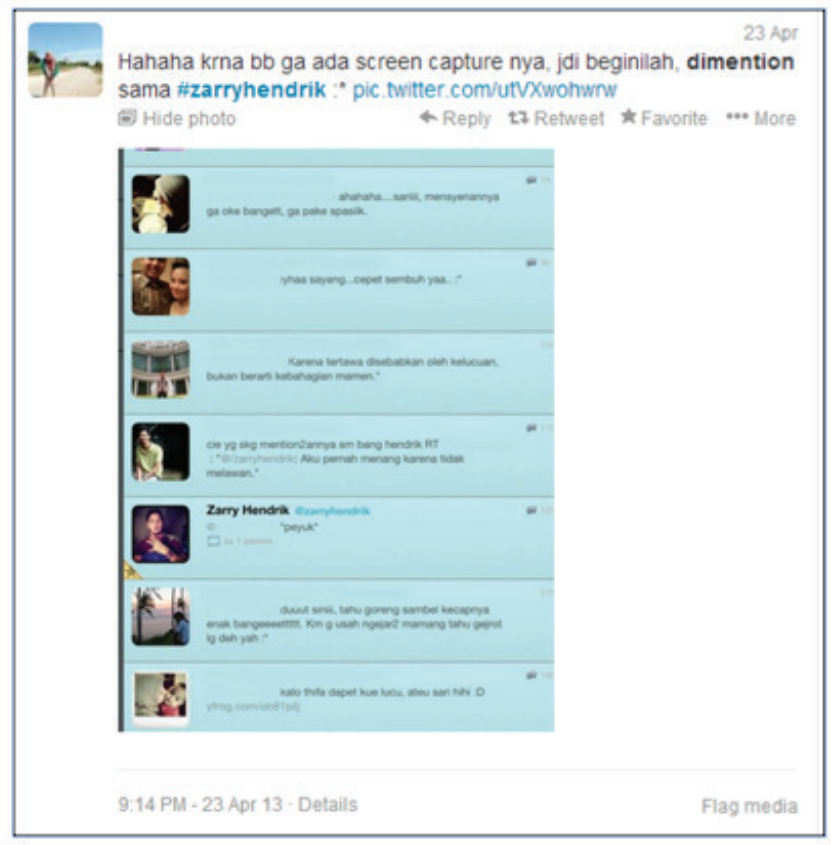

Figure 1. 9: Interaction as achievement

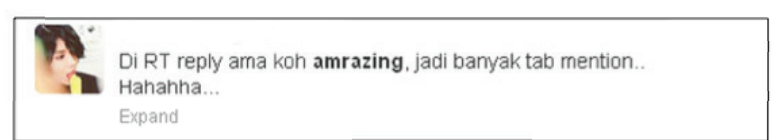

@aMrazing Kak, tab mention Ay penuh gara-gara
follower Kakak semua :।
Detalls

Figure 1. 10: Interaction as endorsement

Female user (1): Since amrazing RT (Retweeted) and replied (my tweet), I receive a lot of mentions.. Hahahha...

Female user (2): @amrazing Bro,my mention’s tab is full because of your followers :|

In summary, users who frequently interact with selebtwits (by replying their tweets or retweeting with added comments) perceive feedback as an achievement because "receiving a message from a highly followed individual is a status symbol" within the fan community (Marwick \& boyd, 2011, p. 150). Furthermore, they are also pleased if their tweets get retweeted since retweeting practices, which mainly used to engage in a conversation between users and a way to "copying and rebroadcasting" oth-

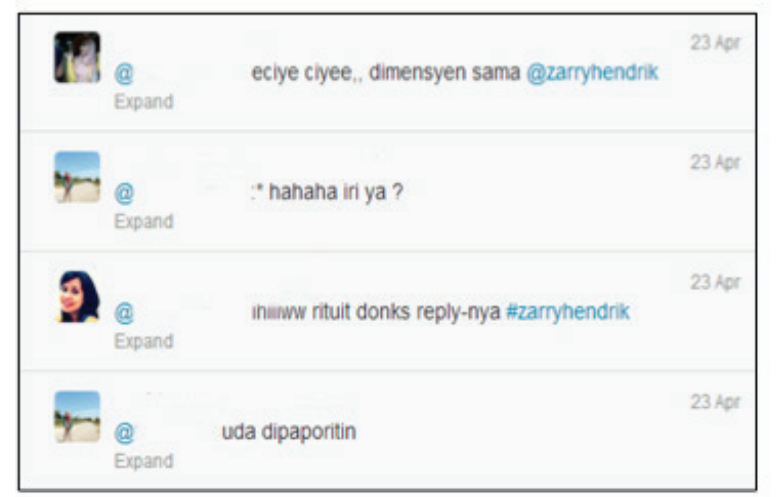


ers' tweets, can also be seen as a form of public endorsement ${ }^{13}$ and a way to increase users' visibility (boyd, et al., 2010).

Some of the respondents in this research interestingly said that that they feel reluctant to interact with selebtwits because they do not know them in person and the only reason they followed selebtwits was for one-way entertainment or information purposes, and hence they do not expect interaction (see figure 11).

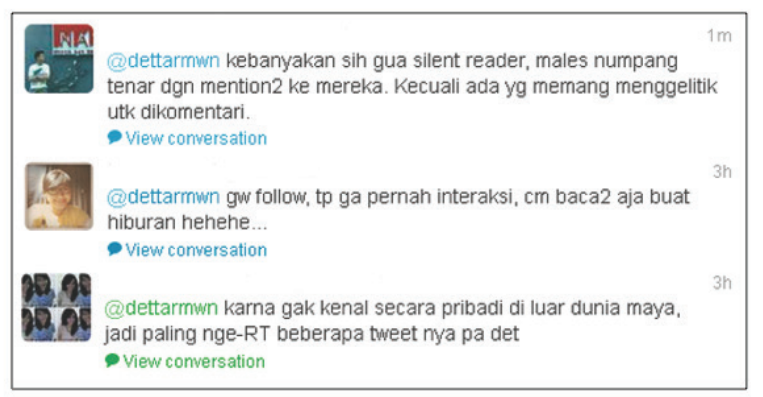

Figure 1. 11: The silent reader

Male user (1): @dettarmwn very often I am just a "silent reader", I do not really like the idea of mentioning them to get their attentions, except if there is something that made me really want to comment on it.

Female user (2): @dettarmwn I follow (these selebtwits) but (I) never interact, (I) only read them for entertainment (laugh).

Female user (3:@dettarmwn Since (i) do not know them other than in the online world, maybe I only retweet some of their tweets.

These people serve as a passive audience of these selebtwits without wanting to know more about them in person. This shows that there are users who are not particularly fond of the idea of interaction. Selebtwits are perceived as only a source of information or entertainment, not 13 There are various motivations for doing retweeet, include: "To amplify or spread tweets to new audiences", "To publicly agree with someone", "To make one's presence as a listener visible" and "To recognize or refer to less popular people or less visible content" (boyd, et al., 2010, p. 6) someone who can be regarded as a "friend". However, they still recognized the influence and the popularity of selebtwits. While the possibility of interactions is not what they have in mind when they follow selebtwits, these people still enjoy their tweets and they do not completely rule out the possibility of interaction if they come across particular tweets or topics which interest them.

\section{SUMMARY \& CONCLUSSION}

Micro-celebrity practices consist of a set of learned techniques that are leveraged differently by individuals to create an online persona for the consumption of others. On Twitter, communication and participation, as well as self-presentation and self-promotion, occur and are intertwined. This research has discussed the concept of selebtwits as ordinary people who become "Twitter celebrities" and how users perceive them. Drawn on the analysis of selebtwits-followers' interactions, it has been found that these selebtwits conduct several strategies to interact with their followers and keep them "connected" by creating a sense of "digital intimacy" (Thompson, 2008).

For some users, the possibility of interaction is the reason why people become loyal followers of selebtwits. For others, however, these selebtwits are seen as merely a source of entertainment or information, where they do not find it is necessary to interact with them. Unlike "parasocial interaction", where the celebrity might be unaware of the existence of their fans, this research found that selebtwits maintain their followers by several strategies such as: stimulated conversation, audience recognition, and various level of self-disclosure. Furthermore, the analysis suggested that from the follower viewpoint, interactions between them are considered as "endorsement" and "achievement".

This research found that Twitter followers are always become an important part of selebtwits as micro-celebrity practitioners in a way such fans are important for celebrities. Within marketing discourses and socio-political activism, selebtwits are perceived in a positive way. However, there are users who uncomfortable with the label and prefer to be called something else such as "Key Opinion Leader" or "Influencer" 
since they feel that the label is perceived negatively by others. However, additional research is necessary to explore this issue and it may be interesting to investigate in more detail how public in general perceive the selebtwits as micro-celebrity practitioners who utilize their online popularity into real life.

Since the dataset used in this research was relatively small, the results cannot be used to generalize the entire discourse of Indonesian Twittersphere; rather, it is best regarded as a "selective snapshot" of micro-celebrity practices in Indonesia. Future study should address the issue about internet access in Indonesia and whether or not it has some effect on the emerging selebtwits phenomenon. It is also important to critically analyze why the majority of the selebtwits comes from Jakarta, Indonesia, and most of them are professional or upper middle-class. Finally, further research using a different methodology and larger dataset may be useful to broaden the study of the micro-celebrity practices happening in today's contemporary society.

\section{REFERENCES}

Boyd, d., Golder, S. \& Lotan, G. (2010). Tweet, tweet, retweet: conversational aspects of retweeting on twitter. Hawaii, International Conference on System Sciences.

Burson-Marsteller. (2012). G20influencers. Accessed 17 June 2013 at http://www.g20influencers.com/summary/indonesia.pdf

Campaign Brief Asia. (2013). Campaign brief Asia. Accessed 28 July 2013 at http://www. campaignbriefasia.com/2013/07/leo-burnett-indonesia-appoints.html.

Daily Social. (2013). Daily social. Accessed 5 May 2013 at http://en.dailysocial.net/post/ understanding-digital-campaigns-in-indonesia

Gramedia. (2012). Gramedia online. Accessed 30 July 2013 at http://www.gramediaonline. com/moreinfo.cfm?Product_ID $=848223$

Grigoriadis, V. (2010). Vanity vair. Accessed 1 July 2013 at http://www.vanityfair.com/ culture/features/2010/02/twitter-201002

Hammersley, M. (1995). What's wrong with ethnography? methodological explorations. London: Routledge.
Hewett, E. (2013). Metro.co.uk. Accessed 3 June 2013 at http://metro.co.uk/2013/03/06/ top-5-celebrity-clothing-lines-from-rihannato-kelly-brook-3529119/

Jakarta Globe. (2013). Jakarta globe. Accessed 6 May 2013 at http://www.thejakartaglobe.com/archive/editorial-social-media-both-awesome-and-bad/

Jakarta Post. (2013). Jakarta post. Accessed 30 July 2013 at http://www.thejakartapost.com/ news/2013/05/07/political-wars-set-heat-social-media.html

Lim, M. (2012). Many clicks but little sticks: social media activism in Indonesia. Journal of Contemporary Asia.

Marwick, A. (2010). tiara.org. Accessed 17 January 2012 at http://www.tiara.org/dissertation/index.html

Marwick, A. \& boyd, d. (2011). To see and be seen:celebrity practise on twitter. convergence: the international journal research into new media technologies, 17(2), p. 139-158.

Marwick, A. E. \& boyd, d. (2010). I tweet honestly, i tweet passionately: twitter users, context collapse, and the imagined audience. New Media \& Society, 13(1), pp. 114-133.

Maulia, E. (2013). Jakarta globe. Accessed 4 May 2013 at http://www.thejakartaglobe.com/health/social-media-addiction-a-new-pathological-disorder/

Paramaditha, A. (2013). Reuters. Accessed 23 August 2013 at http://www.reuters.com/article/2013/08/22/indonesia-twitter-idUSL4N0GF0UV20130822

Porter, J. (2009). bokardo.com. Accessed 22 December 2012 at http://bokardo.com/archives/relationship-symmetry-in-social-networks-why-facebook-will-go-fully-asymmetric/

Ryan, W. G. \& Bernard, H. R. (2003). Techniques to identify themes. Field Methods, 15(1), p. 85-109.

Saleh, D. (2013). ipra.org. Accessed 15 June 2013 at http://www.ipra.org/itl/02/2013/ indonesia-falls-for-social-media-is-jakartathe-world-s-number-one-twitter-city

Satvika, P. (2012a). Slideshare. Accessed 20 072013 at http://www.slideshare.net/anakcerdas/quick-look-to-indonesias-twitterspheres-in-2012

Satvika, P. (2012b). Slideshare. Accessed 17 July 2013 at http://www.slideshare.net/anak- 
cerdas/indonesias-social-media-study-cases-2012? from search $=6$

Semiocast (2012). Semiocast. Accessed 15 January 2013 at http://semiocast.com/en/ publications $/ 201207 \quad 30$ Twitter_reaches half_a billion accounts 140m in the US

Senft, M. T. (2008). Camgirls: celebrity \& community in the age of social networks. New York: Peter Lang Publishing.

Senft, T. (2012). terrisenft.net. Accessed 26 May 2013 at http://www.terrisenft.net/wordpress/publications/
Thompson, C. (2008). Brave new world of digital intimacy. Accessed 17 May 2013 at http://www.nytimes.com/2008/09/07/magazine/07awareness-t.html?pagewanted $=$ all \& $\underline{\mathrm{r}=0}$

Tribun News (2013). Tribun news. Accessed 20 July 2013 at http://www.tribunnews.com/ seleb/2013/01/12/rahne-putri-si-seleb-twittyang-beken-karena-akun-gombalnya

Turner, G. (2010). Ordinary people and the media: the demotic turn. London: Sage Publications $\mathrm{L}$ 